\title{
PROJECT APPROACH TO THE DEVELOPMENT AND IMPLEMENTATION OF THE REGIONAL PROGRAM OF PROMOTING THE CIVIL SOCIETY DEVELOPMENT IN ODESA REGION
}

\author{
Sencha S. A., Bezverkhniuk T. M.
}

\section{INTRODUCTION}

The urgency of civil society development in Ukraine is driven by the steadily growing role of civil society institutions in all spheres of public administration - from promoting reforms at the state and local levels, European integration and e-Government developing to volunteer work and providing assistance to socially vulnerable sections of the population. The development of civil society is one of the most important conditions for Ukraine to become a European country with a high level of democratic values and consolidation of society.

Approval of the National Strategy for Promoting Civil Society Development in Ukraine for 2016-2020 by The Decree of the President of Ukraine of 26.02.2016 No. 68/2016 "On Promoting the Development of Civil Society in Ukraine" became not only recognition of the importance of the influence of public associations on social and political processes in Ukraine but also an expression of the urgent need to develop a constructive dialogue and effective cooperation between civil society and government to address acute social cause.

It is worth noting that this document also acknowledged the existence of artificial barriers in Ukraine for the implementation of public initiatives, the formation and activity of certain types of civil society organizations, the consideration and taking into account of public proposals by public authorities. In order to overcome these barriers and create favorable conditions for the civil society development, the following strategic directions were envisaged: creation of favorable conditions for the formation and institutional development of civil society organizations; ensuring effective procedures for public participation in the formulation and implementation of state, regional policy, resolution of issues of local importance; stimulating the participation of civil society organizations in the socio-economic 
development of Ukraine; creating favorable conditions for cross-sectoral cooperation. Implementation of strategic directions at the regional and local levels has been entrusted to sphere of state administrations. In particular, they had to develop and provide the approval of regional targeted programs for promoting the development of civil society ${ }^{1}$.

Given the many challenges faced by state executive bodies in the regions when planning and organizing engagement with civil society, as well as the significant environmental uncertainty and limited human, financial and time resources, it is appropriate to apply project management methods and tools into this work.

Implementation of project management methodology in the sphere of public administration is devoted to many works of both domestic and foreign scientists - S. Bushuieva, V. Burkova, V. Voropaiev, V. Vorotin, Clifford F. Gray, N. Drahomiretska, I. Mazura, V. Shapiro, Y. Sharov, I. Chikarenko and others. The effectiveness of the project approach to the implementation of territorial innovation strategies has been proved; it is recognized that the use of project management tools is optimal in order to achieve the objectives in the context of scarce resources and in times of crisis of the management object. However, the descriptions of the relevant tools and the particularities of their use in the process of developing and implementing regional targeted programs are not given sufficient attention. In addition, it is extremely important to evaluate the effectiveness of the practical use of project management techniques in public administration.

\section{Experience of applying the project approach in the process of developing a regional targeted program for promoting the civil society development in the Odesa region}

In the process of developing a regional targeted program for promoting the civil society development in Odesa region, it has become extremely useful to apply the logical-system approach - an analytical and management tool, which is now used in one form or another by most one-sided and multilateral international financial assistance organizations, many European organizations also is recommended by the European Commission as a mandatory method of project development for the provision of projects external assistance.

1 Про сприяння розвитку громадянського суспільства в Україні : Указ Президента України від 26 лютого 2016 р. № 68/2016 / Верховна Рада України. URL: http://zakon2.rada.gov.ua/laws/show/68/2016 (Last accessed: 25.02.2020). 
Logical-system approach involves the use of a set of interrelated tools for the purpose of systematic analysis of problems, defining goals, choosing a strategy and logical relationships between the structural elements of a project or program, resulting in a logical structure scheme as a product of analytical activity containing the main project/program elements, namely: goal hierarchy; tasks and/or directions of activity; major external factors that are critical to the successful achievement of goals; indicators and audit sources that help you measure how well your goals are being met $^{2}$.

According to the logical-system approach, the work was divided into the following stages.

1. Systematic analysis of problems in the development of civil society in Odesa region, including the identification of causal relationships between them. At this stage, the cause and effect analysis and construction of the problem tree were used - a hierarchical structure of the tree species, in the central part of which the main problem is indicated, in the upper part - the consequences of the problem, and in the lower part - its causes.

Analysis of the civil society development in Odesa region revealed the following major problems:

- the prevalence of the majority of organizations registered in the region to the territories of cities of region importance and the lack of coverage of other settlements, which reduces the effectiveness of accumulation and implementation of public initiatives and the ability to exercise civic influence on the formation and implementation of state and regional policy;

-insufficient use of the existing capacity of civil society institutions by public authorities to address territorial socially significant problems;

-insufficient activity and preparedness of representatives of public associations and public authorities for public dialogue and constructive solving of problems, insufficient level of civil, political, legal culture, tendency to criticize without constructive proposals, passivity, mutual distrust, in some cases confrontation.

Classification and ranking of problems in the form of a tree allowed:

2 Керівництво 3 управління проєктним циклом. Європейська комісія Europe AID. URL: http://regionet.org.ua/files/PCM_EuropeAid_2004_ua.pdf (Last accessed: 25.02.2020). 
-formulating the main problem addressed by the program insufficient development of civil society in Odesa region and low level of interaction between civil society institutions and public authorities;

-identifying relationships and interrelationships among many problems: thus, the main problems identified are mainly the mobilizing nature of citizen participation in public sector activities, a haphazard and formalized approach to the use of various forms of participatory democracy, the incomplete use of the potential of civil society institutions by public authorities; the components, in particular, the problems of the second level - incomplete use of the potential of civil society institutions - are defined: insufficient involvement of the public for actualization and resolving of socially significant problems, unpreparedness of both parties (both civil society institutions and public authorities) to constructive dialogue; mutual distrust of both parties and passivity in establishing partnerships.

The complete picture of the problem tree is provided in the second part of the Regional Target Program for Promoting Civil Society Development in Odesa region for 2018-2020 3 .

Thus, a considerable amount of information on the state of development of civil society in the region was presented in a compact, easy form for using.

2. Identification of directions of activities on development of civil society in Odesa region, including description of the desired situation. At this stage, situational analysis was used to construct the "AS-IS" and "TO-BE" models. The results of situational analysis and modeling while program development are presented in Table 1.

3 Про затвердження Регіональної цільової програми сприяння розвитку громадянського суспільства в Одеській області на 2018-2020 роки: Рішення Одеської обласної ради від 14 березня 2018 р. № 659-VII / Одеська обласна рада. URL: https:/oda.odessa.gov.ua/statics/pages/files/5af97797d09dc.pdf (Last accessed: 25.02.2020). 


\section{Results of construction of "AS-IS" and "TO-BE" models}

\begin{tabular}{|c|c|}
\hline $\begin{array}{l}\text { Positive facts and processes } \\
\text { (What works?) }\end{array}$ & $\begin{array}{l}\text { Negative facts, imperfect processes } \\
\text { (What does not work yet?) }\end{array}$ \\
\hline $\begin{array}{l}\text { - Significant number of public } \\
\text { associations (as of } 01.01 .2017,5090 \\
\text { public associations have been legalized } \\
\text { by regional justice departments in the } \\
\text { region) }\end{array}$ & $\begin{array}{l}\text { - Low percentage of active public } \\
\text { associations (as of } 01.07 .2017 \text { about } \\
40.1 \% \text { of public associations declare } \\
\text { their activity) }\end{array}$ \\
\hline $\begin{array}{l}\text { - The most numerous public } \\
\text { associations are those aimed at } \\
\text { improving the social and material status } \\
\text { of individual target groups (about } 77 \% \\
\text { of their total) }\end{array}$ & $\begin{array}{l}\text { - A small proportion of youth, } \\
\text { children, women's public associations, } \\
\text { as well as human rights advocacy and } \\
\text { territorial development issues }\end{array}$ \\
\hline $\begin{array}{l}\text { - There are examples of successful } \\
\text { cooperation between public authorities } \\
\text { and public associations (during the } \\
\text { period } 2016 \text { - the first half of } 201765 \\
\text { programs (projects, events) were } \\
\text { carried out (implemented) by public } \\
\text { associations at the expense of local } \\
\text { budgets in the districts of Odesa region. }\end{array}$ & $\begin{array}{l}\quad-\text { Public consultations and } \\
\text { examinations are non-systematic, } \\
\text { episodic (in 2016 - the first half of } 2017 \\
\text { no public consultations were conducted } \\
\text { in five districts of Odesa region; public } \\
\text { councils function only in } 14 \text { districts of } \\
\text { the region) }\end{array}$ \\
\hline $\begin{array}{l}\text { Changes are needed } \\
\text { (What is missing?) }\end{array}$ & $\begin{array}{l}\text { Possible directions for change } \\
\text { (What is possible?) }\end{array}$ \\
\hline $\begin{array}{l}\text { - Active public associations in the } \\
\text { districts of region (on average, } 1.75 \\
\text { public associations per } 1.000 \text { people } \\
\text { function in cities, } 0.81 \text { public } \\
\text { associations per } 1.000 \text { population in the } \\
\text { districts) }\end{array}$ & $\begin{array}{l}\text { - To intensify public consultations } \\
\text { on the formation and implementation of } \\
\text { state policy (Resolution of the Cabinet } \\
\text { of Ministers of Ukraine of } 03.11 .2010 \\
\text { No. 996), facilitate public expertise of } \\
\text { activities of public authorities (CMU } \\
\text { Resolution of 9.11.2008 No. 976) }\end{array}$ \\
\hline $\begin{array}{l}\text { - Active position of public } \\
\text { authorities to establish communication } \\
\text { with the public (in } 13 \text { districts of the } \\
\text { region during the specified period there } \\
\text { were no educational measures on the } \\
\text { development of civil society, nor were } \\
\text { public opinion polls conducted) }\end{array}$ & $\begin{array}{l}\text { - Ensure: creation of } \\
\text { communication platforms for } \\
\text { establishing communications between } \\
\text { public authorities and the public; } \\
\text { educational activities on modern } \\
\text { methods and forms of cooperation } \\
\text { between public authorities and the } \\
\text { public; highlighting best practices for } \\
\text { using different forms of participatory } \\
\text { democracy }\end{array}$ \\
\hline $\begin{array}{l}\text { - Willingness of public } \\
\text { associations to cooperate with public } \\
\text { authorities and desire to take partial } \\
\text { responsibility for solving socially } \\
\text { significant problems (as a result of } 248 \\
\text { public consultations conducted in } \\
\text { cities, only } 13 \text { proposals from public } \\
\text { associations were received) }\end{array}$ & $\begin{array}{l}\text { - Encourage the development by } \\
\text { public associations of projects for the } \\
\text { caring out (implementation) of which } \\
\text { financial support is provided and } \\
\text { facilitate the stable holding of relevant } \\
\text { competitions at all levels of the } \\
\text { executive power (CMU Resolution of } \\
10.10 .2011 \text { No. 1049) }\end{array}$ \\
\hline
\end{tabular}


Thus, as a result, positive and negative factors and processes in the sphere of civil society development of Odesa region were identified, priority tasks that needed to be solved, and possible (regulated by regulatory documents) directions of activities and tools were formulated. However, given the limited resources of public authorities, among the areas of activity and appropriate measures to stimulate the development of civil society in the region, it was necessary to select those that would be, on the one hand, the most effective and necessary to achieve the goals.

3. Selection of optimal directions of activities for civil society development in Odesa region. To optimize the activity of public authorities in the development of civil society in Odesa region, a SWOT analysis was used, using expert evaluation of the importance of external and internal factors that were selected for analysis, as well as their combinations ${ }^{4}$. The object of the analysis was the state of civil society at the time the program was developed. The methodology involved assessing the intrinsic strengths and weaknesses of the study object and the significance and probability of sustainability of external opportunities and threats on specially designed five-point scales. Similarly, a scale was developed to evaluate combinations of external and internal factors - tenpoint, with scores ranging from -5 to 5 points, depending on the direction of the mutual influence of factors.

Further analysis was performed on integral estimates, which were the product of all the obtained by relevant factors points. The sums of integral estimates in the columns of the resulting SWOT matrix allowed us identifying the most significant environmental factors. In this case, the most significant opportunity corresponds with the maximum score, and the threat corresponds with the minimum score. Similarly, the sums of integral estimates in the rows of the resulting matrix allowed us distinguishing the most significant characteristics of the study objects. The strongest side corresponded with the maximum score, the weakest with the minimum. The results of the analysis are presented in Table 2.

The most significant combination of external factors and internal strengths and weaknesses was also determined by the maximum integral estimates obtained at the intersection of rows and columns of the SWOT matrix.

4 Технологія управління соціальними проєктами : монографія / Т.М. Безверхнюк та ін. ОРІДУ НАДУ. Одеса, 2014. 292 с. 
Results of SWOT analysis

\begin{tabular}{|c|c|}
\hline $\begin{array}{l}\text { Strengths } \\
\text { (point) }\end{array}$ & $\begin{array}{c}\text { Weaknesses } \\
\text { (point) }\end{array}$ \\
\hline $\begin{array}{l}\text { Significant number of established } \\
\text { civil society institutes, their branching } \\
\text { of the field and activities (362.4) }\end{array}$ & $\begin{array}{l}\text { Concentration of civil society institutions } \\
\text { in cities of region importance; unevenness } \\
\text { and predominantly situational nature of the } \\
\text { activities } \\
\quad(-425.6)\end{array}$ \\
\hline $\begin{array}{l}\text { Existence of public councils at } \\
\text { executive bodies as communication } \\
\text { platforms }(615.5)\end{array}$ & $\begin{array}{l}\text { Inconsistency and scattered activities of } \\
\text { civil society institutions, low social } \\
\text { movement consolidation }(-537.5)\end{array}$ \\
\hline $\begin{array}{l}\text { Participation of civil society } \\
\text { institutions in advisory bodies at the } \\
\text { executive bodies }(642.5)\end{array}$ & $\begin{array}{l}\text { The reluctance of civil society institutions } \\
\text { to take partial responsibility for addressing } \\
\text { socially significant problems }(-545)\end{array}$ \\
\hline $\begin{array}{l}\text { Participation of civil society } \\
\text { institutions in competitions for the } \\
\text { identification of programs (projects, } \\
\text { events) for which financial support is } \\
\text { provided for carrying out } \\
\text { (implementation) (497.2) }\end{array}$ & $\begin{array}{l}\text { A formalized and haphazard approach in } \\
\text { the use of various forms of interaction } \\
\text { between the public and public authorities; } \\
\text { material dependence of many civil society } \\
\text { institutions (-438) }\end{array}$ \\
\hline $\begin{array}{l}\text { Opportunities } \\
\text { (point) }\end{array}$ & $\begin{array}{l}\text { Threats } \\
\text { (point) }\end{array}$ \\
\hline $\begin{array}{l}\text { Citizens' trust in NGOs declines } \\
\text { relatively less than trust in } \\
\text { government }- \text { there is hope that } \\
\text { expanding activities and enhancing the } \\
\text { activity of CSIs can help to reform the } \\
\text { state and society (43.2) }\end{array}$ & $\begin{array}{l}\text { Outdated methods of work of public } \\
\text { authorities; managerial traditions, formed in the } \\
\text { Soviet times; a small proportion of youth } \\
\text { among civil servants and local government } \\
\text { officials due to very low pay (0) }\end{array}$ \\
\hline $\begin{array}{l}\text { The overwhelming majority of } \\
\text { Ukrainians are convinced that they } \\
\text { must have a real influence on state } \\
\text { decision-making, participate in the } \\
\text { activities of CSIs, in particular in } \\
\text { exercising control over public } \\
\text { authorities (27) }\end{array}$ & $\begin{array}{l}\text { Poor development of information and } \\
\text { legal support and their underestimation, } \\
\text { especially at the level of local self- } \\
\text { government; administrative resource remains } \\
\text { the most popular }(-16.8)\end{array}$ \\
\hline $\begin{array}{l}\text { Ample opportunities to increase } \\
\text { the capacity of CSI representatives } \\
\text { and public authorities, in particular by } \\
\text { operating short-term educational } \\
\text { programs to build knowledge and } \\
\text { skills on new forms and methods of } \\
\text { partnership-based interaction, project } \\
\text { contests, grants, etc. (70) }\end{array}$ & $\begin{array}{l}\text { Lack of free time in the population of the } \\
\text { country; all the time and effort is lost to work, } \\
\text { often in several workplaces, for the financial } \\
\text { support of the family; unfavorable business } \\
\text { climate in the country, high tax burden. A } \\
\text { significant proportion of low- and middle- } \\
\text { income people who have reduced levels of trust } \\
\text { in both government and CSIs }(-28)\end{array}$ \\
\hline $\begin{array}{l}\text { Positive experience in implementing } \\
\text { the latest forms and methods of } \\
\text { cooperation between public authorities, } \\
\text { CSIs and business structures, in } \\
\text { particular, combating corruption and } \\
\text { combating information aggression (37.8) }\end{array}$ & $\begin{array}{l}\text { Absence of a clear and comprehensible } \\
\text { strategy for the development of Ukrainian } \\
\text { society and an appropriate targeted } \\
\text { government policy, compounded by the } \\
\text { political crisis and external aggression, in } \\
\text { particular information (21) }\end{array}$ \\
\hline
\end{tabular}


The most significant combination of external opportunities and strengths, the so-called development points, indicate that to achieve strategic goals, efforts must be focused on:

- seeking opportunities for effective cooperation at the regional and state level to share experience, joint training of civil servants and representatives of civil society institutions, implementation of joint projects for the implementation of modern innovative tools of interaction, cooperation and partnership with public institutions into the practice of public authorities;

- creation of the maximum number of communication platforms for establishing effective communication between public authorities and the public, in particular, ensuring broad coverage of public authorities' activities; ensuring the functioning of optimal communication channels for educational activities and social advertising;

-formation and support of a positive image of civil society institutions, broad coverage of their activities, formation of an understanding of the importance of civil society institutions development in the population, support of public initiatives; creating conditions for strengthening the capacity of civil society institutions.

The most significant combinations of external threats and strengths, the so-called point of defense, indicate that in order to work out the defense mechanisms, efforts should be made to pool resources of public authorities and public associations in order to implement joint projects/measures; as well as combining their own information channels to create an image of partners and demonstrate the success and feasibility of partnership activities, as well as to create an active public position in the population, a sense of responsibility for solving local problems and further development of the region.

It is also appropriate to facilitate the creation and support of an active activity of efficient communication platforms, capable of playing the role of components of a communicative mechanism for promoting the civil society development - public council, youth council, council of entrepreneurs and other subsidiary bodies, which can be created under public authorities.

The most significant interconnections of external opportunities and weaknesses, the so-called stagnation points, show that efforts must be made to strengthen the identified weaknesses in order to successfully complete the tasks, first, facilitating the access of civil society institutions to financial resources, namely the creation of a support 
system for public projects, especially innovative ones, by organizing assistance to civil society institutions in the development of relevant projects and submitting them to competitions.

On the other hand, it would be extremely effective to use the resources of civil society institutions to solve community problems, including the development of social entrepreneurship, to promote the formation of socially responsible businesses; formation of the understanding at the public associations' representatives that public authorities cannot and should not take all responsibility for the state of civil society in the region, that any projects and programs of civil society development are doomed to failure if not actively supported by public associations and the territorial community as a whole.

The most significant combinations of external threats and weaknesses, the so-called crisis points, indicate that in order to prevent a crisis social situation, efforts should be urgently directed to the elimination of mutual misunderstanding between the main forces that ensure the functioning and development of the region, to work out the principles and rules of interaction between authorities civil society institutions (a kind of "rules of the game") that take into account the interests of all parties and are strictly adhered to by all stakeholders.

4. Formulation and analysis of the goals of activities to promote the civil society development in Odesa region. At this stage, a goal tree was built - a hierarchical structure in which the negative situation of the problem tree turned into goals and solutions, which were presented as desired positive achievements, and potential goals were based solely on clearly defined priority problems ${ }^{5}$. To identify specific goals and measures to achieve them, possible directions of activities that were assessed as optimal after the SWOT analysis were considered.

Thus, the achievement of the main goal of the program was envisaged through the achievement of the following specific goals: to ensure the further balanced development of civil society institutions; to ensure systematic public participation in the formation and implementation of state, regional policy, and solving issues of local importance; to stimulate the cooperation of civil society institutions and public authorities on the basis of partnership in updating and solving socially significant problems of territorial development. It should be noted that the lower level of the

${ }^{5}$ A Guide to the Project Management Body of Knowledge (PMBOK guide). 6 ed. Project Management Institute, Inc. Independent Publishers Group. Chicago, IL. 2017. $756 \mathrm{p}$. 
goal tree, which contained the results of the decomposition of specific goals, was subsequently used to formulate the objectives of the activity and the corresponding measures that would provide achieving those goals and the strategic goal in general. The complete image of the goal tree, as well as the problem-target rhombus, which shows the relevance of the identified problems and activity goals, are presented in the second part of the Regional Target Program for Promoting Civil Society in Odesa region for 2018-2020.

\section{Assessment of the effectiveness of practical use of project management methods and tools in the sphere of civil society development in Odesa region}

The evaluation of the effectiveness of the practical use of project management methods and tools in the sphere of civil society development in the Odesa region was made by comparing the main indicators of the state of civil society development. The quantitative data needed to evaluate the effectiveness of the above-mentioned practical use of project management methods and tools is provided in Table 3. The data were obtained by the author from the following sources: the Register of Public Associations ${ }^{6}$; responses to requests for public information from the Main Territorial Administration of Justice in the Odesa region and from the Communications and Information Policy Department of the Odesa State Administration; reports published on the official webportal of the Odesa region state administration ${ }^{7}$ and on the official website of the Communications and Information Policy Department of the Odesa state administration ${ }^{8}$; as well as best practice materials on the use of various forms of participatory democracy, cooperation between public authorities and public associations issued by Communications and Information Policy Department of the Odesa state administration?

6 Реєстр громадських об'єднань / Міністерство юстиції України. URL: https://rgo.minjust.gov.ua/ (Last accessed: 26.02.2020).

7 Публічна інформація / Одеська державна адміністрація. URL: https://oda.odessa.gov.ua/publicna-informacia (Last accessed: 26.02.2020).

8 Програмні документи / Управління комунікацій та інформаційної політики Одеської державної адміністрації. URL: https://uvp.odessa.gov.ua/ programy-i-plany/ (Last accessed: 26.02.2020).

9 Сенча С.А., Колцун Д.Л., Демір В.В. Використання різних форм демократії участі, співпраці органів публічної влади та громадських об'єднань. Матеріали кращих практик / Управління комунікацій та інформаційної 
Table 3

Dynamics of performance indicators of civil society development in the Odesa region

\begin{tabular}{|l|c|c|c|}
\hline \multicolumn{1}{|c|}{ Indicators } & \multicolumn{3}{|c|}{ Years } \\
\cline { 2 - 4 } & $\mathbf{2 0 1 7}$ & $\mathbf{2 0 1 8}$ & $\mathbf{2 0 1 9}$ \\
\hline Number of active public associations, units & 5090 & 5353 & 5612 \\
\hline $\begin{array}{l}\text { Number of public associations in Odessa,\% } \\
\text { of total number }\end{array}$ & 65.22 & 65.19 & 65.45 \\
\hline $\begin{array}{l}\text { Number of public associations in other } \\
\text { cities of Odesa region,\% of total number }\end{array}$ & 10.63 & 10.75 & 10.75 \\
\hline $\begin{array}{l}\text { Number of public associations in the Odesa } \\
\text { region, as a percentage of their total number }\end{array}$ & 24.15 & 24.06 & 23.80 \\
\hline $\begin{array}{l}\text { Number of public associations aimed at } \\
\text { protecting the rights and interests of the } \\
\text { population, as well as territorial } \\
\text { development, as a percentage of their total } \\
\text { number }\end{array}$ & 3.17 & 12.32 & 13.04 \\
\hline Number of public councils, units & 14 & 22 & 24 \\
\hline $\begin{array}{l}\text { Number of public consultations/public } \\
\text { hearings, units }\end{array}$ & - & 80 & 161 \\
\hline $\begin{array}{l}\text { Number of electronic public consultations, } \\
\text { units }\end{array}$ & - & 114 & 161 \\
\hline $\begin{array}{l}\text { Number of public (mass) actions organized } \\
\text { by civil society institutions, units }\end{array}$ & 158 & 53 & 44 \\
\hline $\begin{array}{l}\text { Number of situational protests conducted by } \\
\text { civil society institutions, units }\end{array}$ & 159 & 260 & 404 \\
\hline $\begin{array}{l}\text { Number of programs (projects, activities) } \\
\text { carried out (implemented) by civil society } \\
\text { institutions at the expense of local budgets, } \\
\text { units }\end{array}$ & 65 & 75 & 102 \\
\hline $\begin{array}{l}\text { Number of proposals submitted to the } \\
\text { competition for the identification of } \\
\text { programs projects, events) developed by } \\
\text { civil society institutions for the carrying out } \\
\text { (implementation) of which financial support } \\
\text { is provided at the expense of the regional } \\
\text { budget, units. }\end{array}$ & 0 & 19 & 23 \\
\hline
\end{tabular}

політики Одеської державної адміністрації. URL: https://uvp.odessa.gov.ua/wpcontent/uploads/2019/04/Krashhi-praktyky-2018.pdf (Last accessed: 26.02.2020). 
Thus, according to Table 3, as of December 31, 2017, 5090 public associations were registered in the Odesa region; as of December 31, 2018 , the total number of public associations in the region amounted to 5353, as of December 31, 2018 - reached 5612, which is $4.6 \%$ more than at the beginning of the year.

It is worth noting that these are young and very active organizations, in particular, public associations take an active part in the socio-political life of the region: "Social Movement "Faith, Hope, Love", "Family legal-education club "Odessa Dream", "Assembly" of Peace and Creativity", "Movement of Public Initiatives", Initiative group of volunteers of "Inhabitants of Odessa", "Veterans and Invalids of ATO "Rapira", "Union of Paratroopers of Odessa", Public formation for protection of public order and state border "Public Security Patrol", Odesa region organization "Green leaf", "Association of ATO participants - Odesa region", "Methodological center of ATO participants", "Hearts of mothers of Odesa region", "Veteran Hub Odesa", "Association of veterans of the participants of ATO "South", "Union of Entrepreneurs of Zatoka town settlement".

The most influential are the public organizations formed on the wave of the Maidan and the Revolution of Dignity: "Self-defense of the Maidan of Odesa" (V. Kozhukhar, V. Nachvynov), "Public Security Council" (M. Hordienko), Odesa cell of the all-Ukrainian association "Avtomaidan" (V. Ustymenko), "Odesa maritime self-defense" (G. Korolev), who cooperate with state authorities in the issues of combating separatism and terrorism; as well as charitable foundations: Odesa charitable foundation for the rehabilitation and social adaptation of citizens without specific residence "The Way Home", "Red Cross", "For the future without AIDS", "Way to Freedom", "International Assistance "Good Samaritan", "For the benefit of Odesa". Volunteer associations are active in organizing assistance to internally displaced persons and in material support of the military. NGOs "Volunteer Hundred of Dahlia Severyn", volunteer center "Indifferent people", etc. provide significant assistance to the military personnel in the ATO area.

Thus, these data indicate an increase in civic engagement in the Odesa region, which shows the effectiveness of activities on increasing the proportion of active public associations. In addition, these, especially newly created organizations actively and fruitfully cooperate with public authorities, indicating a gradual decrease in the mutual distrust of public authorities and civil society institutions and the formation of partnerships. 
The share of public associations of the Odesa region, aimed at protecting the rights and interests of the population, as well as territorial development, increased by almost $10 \%$ from 2017 to 2019 , from $3.17 \%$ to $13.04 \%$. This data shows that public associations are ready to take part in solving local problems and take partial responsibility for the further development of the region.

However, the distribution of public associations by type of administrative-territorial entities has hardly changed - their vast majority extends their activity to the territories of cities of region importance and rarely cover other settlements. At the same time, the largest number of active public associations per 1000 people of the population in the cities of Odesa, Belgorod-Dnistrovskyi, Yuzhne, and the smallest number - in Chernomorsk. The largest number of active rayon public associations per 1.000 people in the Baltskyi, Ovidiopolskyi, and Oknianskyi districts, the smallest number - in the Ivanivskyi district. Thus, in 2020, special attention should be paid to educational activities among the territorial communities of Odesa region regarding the importance of civil society development, as the influence and efficiency of district state administrations has sharply decreased as a result of the decentralization reform in 2019 in Ukraine.

The number of public councils in the district state administrations of the Odesa region for the period from 2017 to 2019 has almost doubled from 14 to 24 units (in 26 districts of the region, i.e. $92 \%$ of their total possible number), which is a very significant indicator. The public councils are indeed becoming both communication platforms and partners for public authorities. To support the activity of public councils, as well as to highlight the best examples of their interaction with public authorities, in Odesa region for the first time in 2018 the regional competition "Best public council is a reliable partner" was held and repeated in $2019^{10}$.

For the purpose of the most complete, high-quality informing of the population on activity of district state administrations, structural divisions of region state administration, information about their actions is

10 Про затвердження Положення про проведення обласного конкурсу «Краща громадська рада - надійний партнер»: Наказ управління комунікацій та інформаційної політики Одеської обласної державної адміністрації від 22 жовтня 2018 р. № 23-ОД / Управління комунікацій та інформаційної політики Одеської обласної державної адміністрації. URL: https://uvp.odessa.gov.ua/wp-content/uploads/2018/11/000204213600.pdf (Last accessed: 26.02.2020). 
regularly reported on the official web-portal of the Odesa region state administration in the sections "News of districts", "Announces", "Announcements". There is also a continuing awareness of the media about current events conducted with the assistance of structural divisions of region state administrations, district state administrations, public organizations, etc. The activity of using social networks by local authorities and the quality of their filling is quite high.

Information related to the organization and conduction of public consultations is published in a specially created section "Public Consultation" on the official website of the executive body. On the official web-portal of Odesa region in section "For citizens" the subheading "Civil society and power" is introduced, which contains sections "Public council" and "Consultations with the public, where relevant information is published.

In addition, electronic consultations with the public, as well as full information about the organization and holding of public consultations on the official web-portal of the Odesa region and the official website of the Department of communications and information policy of the Odesa region state administration were introduced for the first time in the region state administration.

Accordingly, the number and effectiveness of public consultation both public consultation and electronic consultations - has increased. In particular, in 2019, 194 public consultations were conducted in the region state administrations of the Odesa region, of which 136 discussions of regulatory and other acts of district state administrations, which is $70 \%$ of their total number. As a result of discussions on regulatory and other acts, 18 proposals of civil society institutions were submitted and taken into account. 37 public consultations were held by the region state administration, 7 of which discussed regulatory and other acts of the region state administration, which is $19 \%$ of their total number. As a result of discussions on regulatory and other acts, 2 proposals of civil society institutions were submitted and taken into account.

Accordingly, the number of public (mass) actions organized by civil society institutes in the Odesa region for 2018-2019 decreased from 53 to 44 , which indicates the establishment of effective interaction between public authorities and civil society institutes, finding them more effective forms and methods of joint solution of regional and local issues. The establishment of effective cooperation is also evidenced by the growing number of programs (projects, activities) carried out 
(implemented) by civil society institutes at the expense of local budgets; financial support to public associations by public authorities.

At the same time, the number of situational protests held by public associations has increased. In particular, in 2019, 404 protest actions were conducted in the cities of region and district importance of Odesa region by civil society institutes (45 in January-March, 82 in April-June, 277 in July-December, from 3 to 1500 persons, average duration - an hour) mostly socio-economic in nature, which indicates an increase in the activity and mobility of public associations, increasing their attention to socio-political and socio-economic changes and the speed of response to them.

The most striking was the situation related to the competition of programs (projects, activities) developed by civil society institutions for the carrying out (implementation) of which is provided with financial support from the funds of the regional budget of the projects. In September 2017, the region state administration approved the application forms for the mentioned competition ${ }^{11}$, and in November 2017 the competition was announced. However, no competitive bids were submitted to the region state administration, which once again confirmed the public's unwillingness to cooperate with the executive authorities.

In March 2018, the next competition was announced to identify programs (projects, activities) developed by civil society institutions to be carried out (implemented) in 2019 at the expense of the region budget. However, during the three-month deadline for adopting the documents, civil society institutions have not submitted any competitive bids for the second time.

In order to create the proper conditions for the institutional development of civil society institutions, to train their representatives of the technology of preparation of competitive bids by the region state administration, the term of acceptance of competitive bids for one month was extended and a thematic short-term seminar "Development of competitive bids to participate in call for proposals" was initiated from 25 to 27 June 2018 for 20 representatives of civil society organizations

11 Про затвердження форм документів для проведення конкурсу з визначення програм (проєктів, заходів), розроблених інститутами громадянського суспільства, для виконання (реалізації) яких надається фінансова підтримка за рахунок коштів обласного бюджету: розпорядження голови Одеської обласної державної адміністрації від 27 вересня 2017 р. № 851/А-2017 / Одеська обласна державна адміністрація. URL: https://oda.odessa.gov.ua/statics/categories/files/5aeda7c218b75.pdf (Last accessed: 26.02.2020). 
of Odesa region at the Odessa Regional Institute for Public Administration of the National Academy of Public Administration under the President of Ukraine by the Project Management Department. As a result of the mentioned seminar, 19 bids were submitted to the region state administration, 14 of which were admitted to the competition. As a result, of the second such seminar, in 2018, another 20 representatives of civil society organizations from the Odesa region received practical skills in developing competitive bids for participation in various project contests. In addition, 16 seminar attendees expressed their desire to study at the institute.

Therefore, applying a logical-structural approach allowed us to logically link the identified problems, goals, proposed tasks and activities, adequately organize the activities to achieve the goals and obtain the planned results.

However, the logical-structural approach is only an analytical tool; it does not provide ready-made solutions and cannot replace the experience and competence of program developers. Against this background, the analysis of the effectiveness of the application of specific project management tools in the practical work of public authorities requires further scientific research, and it is necessary to disseminate relevant positive experience and take measures to acquire relevant competencies for civil servants and local self-government officials.

\section{CONCLUSIONS}

The practical experience of using forms and methods of projectoriented public administration in the field of public communication has proved their high efficiency. The main advantages of using these methods, in particular, in the process of developing regional target programs are: standardization of the format of the programs' content, which greatly simplifies the verification of the logic of the proposed tasks and activities, the assessment of their adequacy to the established goals, as well as the logical correlation of the goals and their relevance; simplifying the process of developing a plan for monitoring and evaluating the program, reporting and comparing planned and deliverables; identifying the optimal point of view of the efficiency and resource intensity of activities and appropriate measures.

In the context of activization of the public, establishment of effective interaction of civil society institutions with public authorities on the basis of partnership, through the use of methods and tools of project management in the Odesa region, positive results were achieved, namely: 
-the problems of civil society development of the region are actualized and the optimal ways of their solution have been determined;

- activities of civil society institutes of the region through support of positive image of active public associations, motivation of civil society institutions to actively cooperate with public authorities on the basis of partnership, including through the development of programs (projects, activities) under the conditions of joint financing have been increased;

- participation of the public in the formation and implementation of state, regional policy, solving issues of local importance have been activated;

- capacity of representatives of civil society institutions, in particular by developing knowledge and skills regarding the latest forms and methods of cooperation with public authorities have been increased;

- positive experience and new forms and methods of cooperation between public authorities and civil society institutions have been introduced;

- qualification of representatives of civil society institutions to develop competitive bids for participation in call for proposals, as well as motivation of public authorities to intensify cooperation with the public, the level of transparency and openness of the activity of public authorities have been improved.

\section{SUMMARY}

The article highlights the experience of applying a logic-system approach in the development of a regional target program of civil society development in Odesa region. Particular attention is focused on establishing logical interconnections between the problems of civil society development in Odesa region and the goals of the relevant regional program. The project management methods and tools that were used in the process of planning activities to stimulate civil society development in Odesa region are described, as well as the obtained results. Ways and measures for cooperation between state authorities and civil society institutes in the Odesa region in the aspect of realization of the National strategy of promoting civil society development in Ukraine for 2016-2020 have been suggested.

The quantitative indicators characterizing the state and dynamics of civil society development in the Odesa region for the period 2017-2019 are presented. Positive results were analyzed in the context of establishing effective interaction of civil society institutions with public 
authorities on the basis of partnership, achieved through the use of project management methods and tools. The experience of development and implementation of atypical methods for activating the public in Ukraine is covered.

\section{REFERENCES}

1. Про сприяння розвитку громадянського суспільства в Україні : Указ Президента України від 26 лютого 2016 р. № 68/2016 / Верховна Рада України. URL: http://zakon2.rada.gov.ua/laws/show/ 68/2016 (Last accessed: 25.02.2020).

2. Керівництво 3 управління проєктним циклом. Європейська комісія - EuropeAID. URL: http://regionet.org.ua/files/PCM EuropeAid_2004_ua.pdf (Last accessed: 25.02.2020).

3. Про затвердження Регіональної цільової програми сприяння розвитку громадянського суспільства в Одеській області на 20182020 роки: рішення Одеської обласної ради від 14 березня 2018 р. № 659-VII / Одеська обласна рада. URL: https://oda.odessa.gov.ua/ statics/pages/files/5af97797d09dc.pdf (Last accessed: 25.02.2020).

4. Технологія управління соціальними проєктами : монографія / Т.М. Безверхнюк та ін. ОРІДУ НАДУ. Одеса, 2014. 292 с.

5. A Guide to the Project Management Body of Knowledge (PMBOK guide). 6 ed. Project Management Institute, Inc. Independent Publishers Group. Chicago, IL. 2017.756 p.

6. Реєстр громадських об'єднань / Міністерство юстиції України. URL: https://rgo.minjust.gov.ua/ (Last accessed: 26.02.2020).

7. Публічна інформація / Одеська державна адміністрація. URL: https://oda.odessa.gov.ua/publicna-informacia (Last accessed: 26.02.2020).

8. Програмні документи / Управління комунікацій та інформаційної політики Одеської обласної державної адміністрації. URL: https://uvp.odessa.gov.ua/programy-i-plany/ (Last accessed: 26.02.2020).

9. Сенча С.А., Колцун Д.Л., Демір В.В. Використання різних форм демократії участі, співпраці органів публічної влади та громадських об'єднань. Матеріали кращих практик. Управління комунікацій та інформаційної політики Одеської обласної державної адміністрації. URL: https://uvp.odessa.gov.ua/wpcontent/uploads/2019/04/Krashhi-praktyky-2018.pdf (Last accessed: 26.02.2020). 
10. Про затвердження Положення про проведення обласного конкурсу «Краща громадська рада - надійний партнер»: Наказ управління комунікацій та інформаційної політики Одеської обласної державної адміністрації від 22 жовтня 2018 р. № 23-ОД / Управління комунікацій та інформаційної політики Одеської обласної державної адміністрації. URL: https://uvp.odessa.gov.ua/wpcontent/uploads/2018/11/000204213600.pdf (Last accessed: 26.02.2020).

11. Про затвердження форм документів для проведення конкурсу з визначення програм (проєктів, заходів), розроблених інститутами громадянського суспільства, для виконання (реалізації) яких надається фінансова підтримка за рахунок коштів обласного бюджету: розпорядження голови Одеської обласної державної адміністрації від 27 вересня 2017 р. № 851/A-2017 / Одеська обласна державна адміністрація. URL: https://oda.odessa.gov.ua/statics/ categories/files/5aeda7c218b75.pdf (Last accessed: 26.02.2020).

12. Про організацію проведення конкурсу з визначення програм (проєктів, заходів), розроблених інститутами громадянського суспільства, для виконання (реалізації) яких у 2019 році надається підтримка за рахунок коштів обласного бюджету: розпорядження голови Одеської обласної державної адміністрації від 30 березня 2018 р. № 300/А-2018 / Одеська обласна державна адміністрація. URL: http://oda.odessa.gov.ua/statics/categories/files/5aec2293 c2d7b.pdf (Last accessed: 26.02.2020).

\section{Information about authors:} Sencha S. A.,

Master in Public Administration, Postgraduate Student at Project Management Department Odessa Regional Institute for Public Administration of the National Academy for Public Administration under the President of Ukraine 22, Henuezka Str., Odessa, 65009, Ukraine

Bezverkhniuk T. M., Doctor of Sciences in Public Administration, Professor,

Chair of the Project Management Department Odessa Regional Institute for Public Administration of the National Academy for Public Administration under the President of Ukraine 22, Henuezka Str., Odessa, 65009, Ukraine 